\title{
Devazepide suppresses cell proliferation and migration, and induces apoptosis in bladder carcinoma
}

\author{
Hengzhe Zhang, Xiang Bao, Jian Zhang, Qiang Hu, Bingbing Wei \\ Department of Urology, The Affiliated Wuxi People's Hospital of Nanjing Medical University, Wuxi, China \\ Contributions: (I) Conception and design: B Wei; (II) Administrative support: Q Hu; (III) Provision of study materials or patients: H Zhang; (IV) \\ Collection and assembly of data: H Zhang; (V) Data analysis and interpretation: H Zhang; (VI) Manuscript writing: All authors; (VII) Final approval \\ of manuscript: All authors. \\ Correspondence to: Qiang Hu; Bingbing Wei. Department of Urology, The Affiliated Wuxi People's Hospital of Nanjing Medical University, Wuxi \\ 214023, China. Email: hq_wxph@163.com; urowbb@163.com.
}

\begin{abstract}
Background: This study aimed to examine the effects of devazepide on the proliferation, migration, and apoptosis of human bladder cancer (BC) 5637 cells, and its mechanism.

Methods: A cell counting kit-8 (CCK-8) for cell viability assays, a colony formation assay, and immunofluorescence were applied to detect the effects of devazepide on the proliferation of 5637 cells. Cell cycle assay, cell apoptosis assay and wound healing assay were performed to detect the effects of devazepide on the cell cycle, apoptosis, and migration of 5637 cells. The protein expression of CyclinD1, Bcl-2associated X protein (Bax), poly ADP-ribose polymerase 1 (PARP1), and Cleaved Caspase-3 in 5637 cells was detected by a western blot assay.

Results: The proliferation of 5637 cells was significantly inhibited $(\mathrm{P}<0.001)$ after incubation with 12, 25, and $50 \mu \mathrm{M}$ devazepide for 48 and $72 \mathrm{~h}$. A treatment of $25 \mu \mathrm{M}$ devazepide for $48 \mathrm{~h}$ induced G1-S cell cycle arrest and apoptosis $(\mathrm{P}<0.01)$, and inhibited cell migration $(\mathrm{P}<0.05)$. By western blot assay, we found that devazepide can down-regulate CyclinD1 expression, and up-regulate Bax, PARP1, and Cleaved Caspase-3 expression.

Conclusions: Devazepide inhibits the migration and proliferation of human BC 5637 cells by arresting the G1-S cell cycle, and induces cell apoptosis.
\end{abstract}

Keywords: Devazepide; bladder cancer (BC); cell proliferation; cell cycle; migration; apoptosis

Submitted Apr 08, 2021. Accepted for publication May 19, 2021.

doi: $10.21037 /$ tau-21-409

View this article at: http://dx.doi.org/10.21037/tau-21-409

\section{Introduction}

Bladder cancer (BC) is a common urological carcinoma on the bladder mucous membrane. In the United States, $\mathrm{BC}$ is the 4th most common cancer in men and the 11th in women (1). Just like the other malignancies in the urinary system, BC has the biological potential for recurrence, metastasis, and drug resistance. Research has shown that smoking and other genetic and environmental factors can boost the occurrence and development of BC (2). For non-muscle-invasive $\mathrm{BC}$ (which occurs in almost $75 \%$ of first-visit patients), the main therapeutic approach is the complete resection of the tumor (3). Similar to other tumors, the biological manifestations of BC include cell multiplication, apoptosis dysfunction, invasion, and metastasis (4). Recurring tumors can develop into muscleinvasive BC, and malignancy can substantially increase. Intravesical chemotherapy or a Bacille Calmette-Guérin (BCG) vaccine are regularly used to reduce post-operative recurrence in BC. However, the toxic side effects and drug resistance limited the values of existing chemotherapy drugs. Thus, the screening of drugs aimed at the uncontrolled proliferation, invasion, and migration of $\mathrm{BC}$ cells is of great significance. 
Devazepide is a derivative of benzodiazepine that acts as a cholecystokinin-A (CCK-A) receptor antagonist, and antagonizes CCK's physiological and behavioral effects. Research has shown that devazepide can have an antitumor effect on the growth of multiple types of human cancer. For example, devazepide is useful in inhibiting the proliferation of colonic cancer cells, pancreatic cancer, and Ewing tumors (5-7).

The data show that devazepide blocks CCK-A receptors, which can be activated by CCK-8s, and significantly reduces HT-29 cell division and increases apoptosis- and necrosisinduced cell death (5). Devazepide can also prevent tumor emboli and metastasis through a mechanism involving vascular endothelial growth factor A (6). Research has also shown that these effects on Ewing tumor cell viability appear to be attributable to the apoptosis-inducing effects of devazepide (7).

The CCK receptor (CCKR) is supposed to influence the expression of downstream genes in human BC, leading to cell survival, angiogenesis, and invasion (8); however, research on the effects of devazepide is limited. Assuming the anti-tumor potential of devazepide in BC, we systematically evaluated the effects of devazepide on the proliferation and apoptosis of BC cell lines 5637 in vitro. Specifically, this study sought to examine the effects of devazepide on 5637 cells. Due to the particularity of bladder intravesical instillation, the application of Devazepide to $\mathrm{BC}$ cells is more direct, and the concentration of devazepide can be better controlled, leading to a broader application prospect. We firstly examined whether devazepide can inhibit cell growth, migration, and promote the apoptosis of 5637 cells. We preliminarily explored the underlying mechanism, which is expected to contribute to a potential therapy for BC. We present the following article in accordance with the MDAR reporting checklist (available at http://dx.doi.org/10.21037/tau-21-409).

\section{Methods}

\section{Experimental cells and main reagents}

Human BC 5637 cells were provided by Shanghai Cell Bank of the Chinese Academy of Sciences, Shanghai, China. Devazepide (obtained from Tocris Bioscience, UK) was dissolved in absolute ethanol to $50 \mathrm{mM}$. Dulbecco's modified Eagle's medium (DMEM), trypsin, ethylenediaminetetraacetic-acid solution, and fetal bovine serum (FBS) were obtained from GIBCO, USA. An annexin
$\mathrm{V}$, fluorescein isothiocyanate (FITC) apoptosis detection kit and a cell counting kit-8 (CCK-8) were purchased from Dojindo (Kumamoto, Japan). CyclinD1 antibody (BS1741), Bcl-2-associated X protein (Bax) antibody (BS2538), goat anti-rabbit immunoglobulin $\mathrm{G}(\mathrm{IgG})(\mathrm{H}+\mathrm{L})$-FITC and horseradish peroxidase (HRP) labeled anti-rabbit secondary antibody were purchased from Bioworld, USA. Ki67 antibody (ab16667), Tubulin antibody (ab7291), PARP1 antibody (ab191217), and Cleaved Caspase-3 antibody (ab32042) were acquired from Abcam, UK.

\section{Cell culture and treatment}

5637 cells were cultured in DMEM cell culture solution supplemented with $10 \%$ FBS and $1 \%$ penicillin/ streptomycin, and placed in an incubator at $37{ }^{\circ} \mathrm{C}$ in $5 \%$ carbon dioxide $\left(\mathrm{CO}_{2}\right)$. Cells were exposed to 6-50 $\mu \mathrm{M}$ dvazepide and harvested at the designated time points.

\section{CCK-8 assay}

Human 5637 cells were seeded in 96-well-culture plates and treated with or without $6,12,25$, or $50 \mu \mathrm{M}$ devazepide for 24 to $72 \mathrm{~h}$. A $10 \mu \mathrm{L}$ CCK-8 was added into each well, and the cells were hatched in the dark for $1 \mathrm{~h}$. A microplate reader was used to quantify the optical density of the cells at $450 \mathrm{~nm}$.

\section{Colony formation assay}

About 2,000 of 5637 cells were inoculated into $6 \mathrm{~cm}$ plates and incubated in DMEM containing 10\% FBS and 1\% penicillin/streptomycin with or without $25 \mu \mathrm{M}$ devazepide for 7 days. They were then washed with PBS twice and fixed with paraformaldehyde for $15 \mathrm{~min}$, stained with crystal violet for $2 \mathrm{~min}$ and cleaned with PBS. The plate was photographed, and the numbers of the colonies were counted using Image $\mathbf{J}$ software.

\section{Wound bealing assay}

5637 cells were seeded onto 6-well plates and cultured to full confluence. A wound was created in the center of each well. Next, they were carefully washed twice with PBS to remove any detached cells, and the medium was replaced with FBS free DMEM containing devazepide $(0,25$, or $50 \mu \mathrm{M})$ and then incubated at $37^{\circ} \mathrm{C}$ for $48 \mathrm{~h}$. The wound 
was observed and photographed, and the relative wound healing rates were calculated.

\section{Apoptosis assay}

5637 cells were inoculated into 6-well plates and incubated with or without $25 \mu \mathrm{M}$ devazepide for $48 \mathrm{~h}$. After being washed with PBS, the cells were resuspended in a $1 \times$ Annexin $\mathrm{V}$ binding buffer. The resulting cultures were treated with Annexin V-FITC and PI reagent for $15 \mathrm{~min}$ in the dark. Finally, the apoptosis was measured using a BD FACSCanto II Flow Cytometer.

\section{Cell cycle assay}

5637 cells were cultured in a medium containing devazepide (0 or $25 \mu \mathrm{M}$ ) for $48 \mathrm{~h}$, and were fixed with $70 \%$ precooled ethanol overnight at $4{ }^{\circ} \mathrm{C}$. The cells were then treated with PBS containing Triton X-100 (0.2\%), ribonuclease A $(100 \mu \mathrm{g} / \mathrm{mL})$ and Propidium Iodide (PI) $(50 \mu \mathrm{g} / \mathrm{mL})$ for 1 hour at $4{ }^{\circ} \mathrm{C}$ in the dark, followed by flow cytometry.

\section{Western blot assay}

After treatment with devazepide (0 or $25 \mu \mathrm{M}), 5637$ cells were homogenized in a ristocetin-induced platelet aggregation lysis buffer to which a protease inhibitor and phenylmethylsulfonyl fluoride (Beyotime Biotechnology, Shanghai, China) lysate were added to isolate the total protein of each group. The total protein was loaded into sodium dodecyl sulfate-polyacrylamide gel, separated by electrophoresis, and transferred to a polyvinylidene fluoride (PVD) membrane. The PVDF membrane was blocked with $5 \%$ skim milk for $1 \mathrm{~h}$ and washed with tris-buffered saline (TBST) for 10 min 3 times. The membrane was incubated with the primary antibodies at $4{ }^{\circ} \mathrm{C}$ overnight and washed with TBST, and then incubated with HRPconjugated secondary antibody (goat anti-rabbit) for $1 \mathrm{~h}$ at room temperature. The colors of the bands were developed with an enhanced luminol-based chemiluminescent kit (Beyotime), and photographs were taken using a chemiluminescent imaging system. Image J software was used to analyze the gray values.

\section{Immunofuorescence}

5637 cells were seeded onto coverslips and treated with devazepide ( 0 or $25 \mu \mathrm{M})$ for $48 \mathrm{~h}$. The cells washed with
PBS were fixed in 4\% paraformaldehyde for $15 \mathrm{~min}$ and permeabilized with $0.3 \%$ Triton $\mathrm{X}-100$ for $30 \mathrm{~min}$ at room temperature. After being blocked with $2 \%$ bovine serum albumin for $1 \mathrm{~h}$, the slides were incubated with a primary antibody of $\mathrm{Ki} 67$ (1:200) overnight at $4{ }^{\circ} \mathrm{C}$ and goat antirabbit IgG $(\mathrm{H}+\mathrm{L})$-FITC (1:500) in the dark for $2 \mathrm{~h}$ at room temperature. Cells were stained with 4',6-diamidino2-phenylindole (DAPI), and then viewed using an EVOS FL Auto Imaging System (ThermoFisher, USA).

\section{Statistical analysis}

We repeated all the experiments independently at least 3 times and used a one-way analysis of variance and Student's $t$-test to analyze the statistical significance among groups by GraphPad Prism 8.0.2 (GraphPad Software, USA) and SPSS 22.0 (IBM Corporation, USA). The measurement data were expressed as mean \pm standard deviation $(\bar{x} \pm \mathrm{SD})$. $\mathrm{A} \mathrm{P}<0.05$ indicated statistical significance; $\mathrm{NS}$, not significant; ${ }^{*}, \mathrm{P}<0.05 ;{ }^{* *}, \mathrm{P}<0.01 ;{ }^{* * *}, \mathrm{P}<0.001 ;{ }^{* * * *}, \mathrm{P}<0.0001$.

\section{Results}

\section{Devazepide inhibits the proliferation of human BC cells in vitro}

In an attempt to demonstrate the effects of devazepide on the proliferation of $\mathrm{BC}$ cells, we respectively treated human 5637 BC cells with devazepide at concentrations of 0,6 , 12,25 , and $50 \mu \mathrm{M}$ for 24,48 , and $72 \mathrm{~h}$. CCK-8 assays were performed to examine the effects of devazepide on cell viability. The results indicated that the groups exposed to devazepide at 6 to $50 \mu \mathrm{M}$ for $24 \mathrm{~h}$ showed no significant difference $(\mathrm{P}>0.05)$ compared to the control group (Figure 1). However, the difference was statistically significant $(\mathrm{P}<0.001)$ when the cells were treated with concentrations of 12,25 , and $50 \mu \mathrm{M}$ for 48 and $72 \mathrm{~h}$, and the inhibitory effect was more obvious as treatment time was prolonged and the concentration of devazepide was increased.

We evaluated the capacity for colony formation in 5637 cells after incubation with or without $25 \mu \mathrm{M}$ devazepide, and found that the number of devazepide-treated cell clones was significantly fewer and smaller than the untreated clones $(\mathrm{P}<0.001)$ (Figure 2).

Further, the devazepide-treated and untreated 5637 cells on coverslips were detected with indirect immunofluorescence. The results showed that in 5637 cells, the fluorescence intensity for Ki67 decreased in the 
A

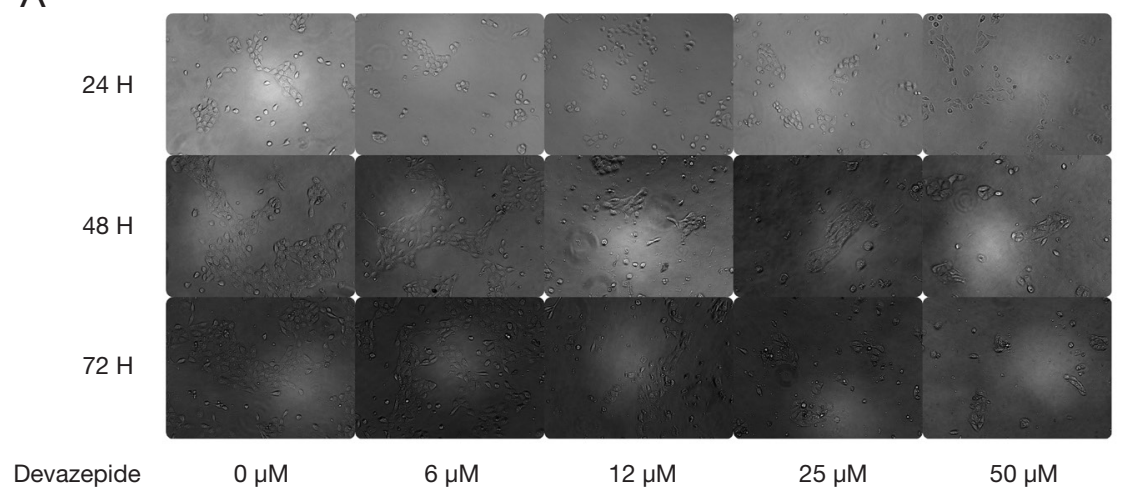

C

$24 \mathrm{H}$

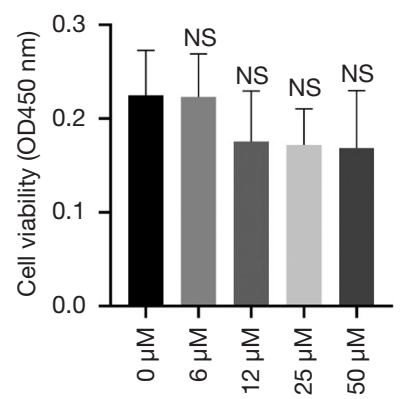

$48 \mathrm{H}$

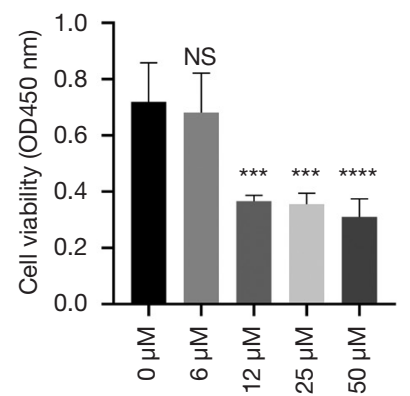

B

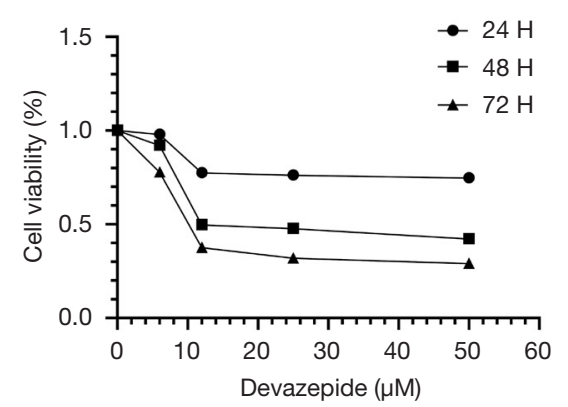

E

$72 \mathrm{H}$

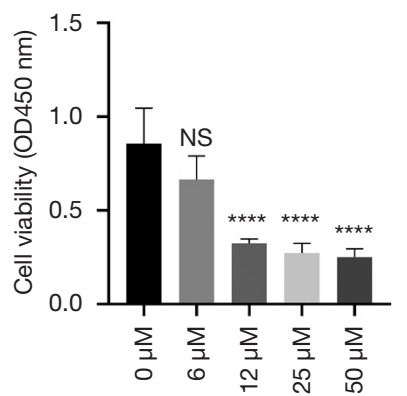

Figure 1 Devazepide inhibited in vitro cell viability of BC 5637 cells in a time- and dose-dependent manner. The proliferation of 5637 cells were detected by a CCK-8 assay after treatment with devazepide $(0,6,12,25$, or $50 \mu M)$ for 24, 48, and 72 h (A,B). Statistical comparisons between the devazepide-treated groups and the control groups showed that, at 48 and $72 \mathrm{~h}$, the cell viabilities of 5637 cells were significantly reduced under the effect of indicated concentrations of devazepide $(\mathrm{C}, \mathrm{D}, \mathrm{E})$. ***, $\mathrm{P}<0.001 ;{ }^{* * * *}, \mathrm{P}<0.0001$. Original magnification, $\times 100$. $\mathrm{BC}$, bladder cancer; CCK-8, cell counting kit-8; NS, not significant.

devazepide-treated group than the control group (Figure 2).

At a molecular level, we treated 5637 cells with $25 \mu \mathrm{M}$ devazepide for 12 and $24 \mathrm{~h}$ to examine the effects of devazepide on the expression of CyclinD1 protein in 5637 cells. The result of a western blot analysis showed that devazepide inhibited the expression of CyclinD1 protein $(\mathrm{P}<0.05)$ (Figure 2). However, the difference between the $12 \mathrm{~h}$ group and the $24 \mathrm{~h}$ group was not significant.

\section{Devazepide sensitizes human BC cells to apoptosis in vitro}

Flow cytometry was conducted to determine the effects of devazepide on the apoptosis of 5637 cells. The apoptotic rates of 5637 cells treated with $25 \mu \mathrm{M}$ of devazepide for $48 \mathrm{~h}$ were dramatically higher than those of the control groups $(\mathrm{P}<0.01)$; thus, devazepide induced cell apoptosis (Figure 3).
To further explore the effects of devazepide in relation to the apoptosis of 5637 cells, we determined the expression levels of apoptosis-related proteins (i.e., Bax, PARP1, and Cleaved Caspase-3) in 5637 cells after incubation with Devazepide for 12 and $24 \mathrm{~h}$. The relative expression of Bax, PARP1, and Cleaved Caspase-3 protein was more increased in the devazepide-treated group than the untreated control group, and the diversity was more evident with the prolongation of treatment time (Figure 3).

\section{Devazepide restrained cell cycle and migration}

In an attempt to explain the mechanism underlying cell proliferation inhibited by devazepide, we examined whether devazepide would also affect 5637 cell cycle progression. The cells incubated with $25 \mu \mathrm{M}$ devazepide for $48 \mathrm{~h}$ were 
A

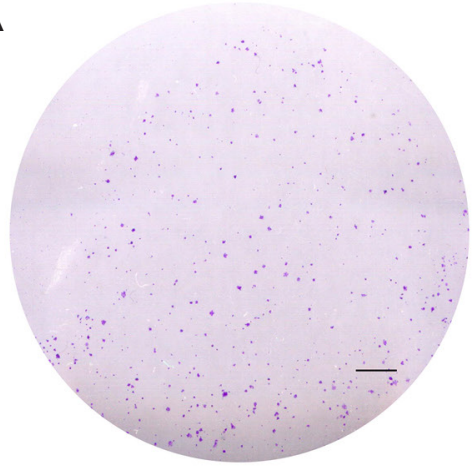

Control

C

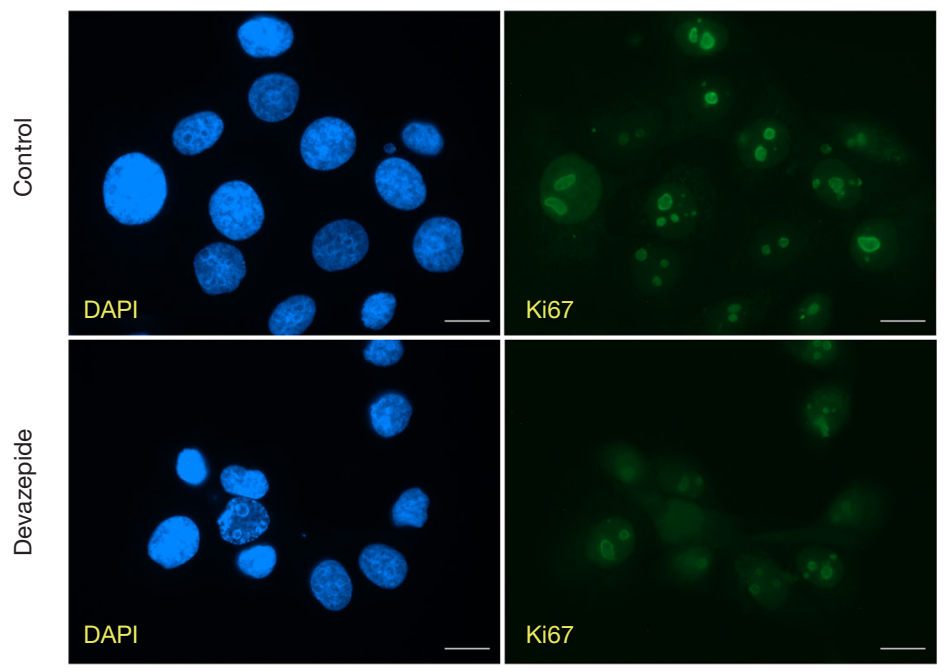

Devazepide $(25 \mu \mathrm{M})$

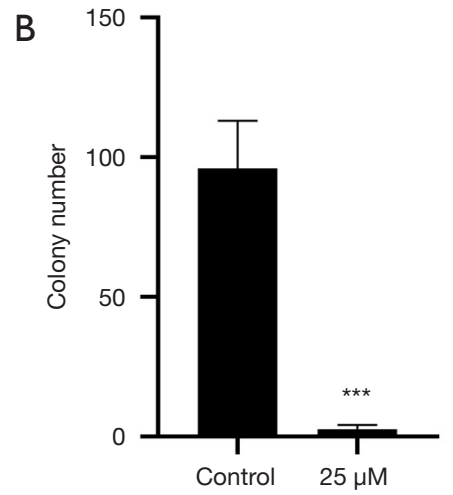

D

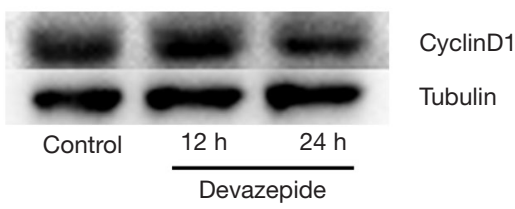

E

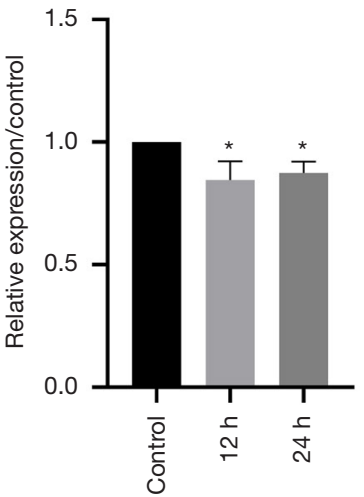

Figure 2 Devazepide inhibited cell proliferation and colony formation of bladder cancer 5637 cells. The cell colonies were stained with crystal violet, and then captured and counted, scale bar: $5 \mathrm{~mm}$ (A). Devazepide decreased the cell colonies (B). We photographed the devazepide-treated 5637 cells and untreated cells, which were stained with Ki67 and DAPI, scale bar: $20 \mu \mathrm{m}(\mathrm{C})$. A western blot was performed to evaluate the expression of CyclinD1 protein in 5637 cells incubated with $25 \mu \mathrm{M}$ devazepide for 12 and $24 \mathrm{~h}$ (D). The results represented the mean $\pm \mathrm{SD}$ for three independent experiments (E). CyclinD1 expression was normalized to Tubulin in 5637. *, $\mathrm{P}<0.05$; ${ }^{* * *}$, $\mathrm{P}<0.001$. SD, standard deviation; DAPI, 4',6-diamidino-2-phenylindole.

stained with PI, and cell cycle phase populations were then determined by flow cytometry. G1-S phase cell cycle arrest was induced in devazepide-treated 5637 cells, accompanied by an increase in cells in the $\mathrm{G} 1 / \mathrm{G} 0$ phase $(\mathrm{P}<0.01)$ and cooccurrent reductions in cells in the $\mathrm{S}$-phases and $\mathrm{G} 2 / \mathrm{M}$ phases $(\mathrm{P}<0.05)$ (Figure 4).

The results of the wound healing experiments showed that 5637 cell migration was more suppressed in the devazepide-treated group than the untreated group (Figure 4).

\section{Discussion}

$\mathrm{BC}$ is the second most common urogenital cancer, and due to its high recurrence and mortality, it is considered one of the deadliest malignant tumors (1). At present, different methods are used to treat BC depending on the pathological stage and grade (9). Intra-bladder infusion chemotherapy is an important method for preventing the recurrence or progression of $\mathrm{BC}$. However, the side effects 
A
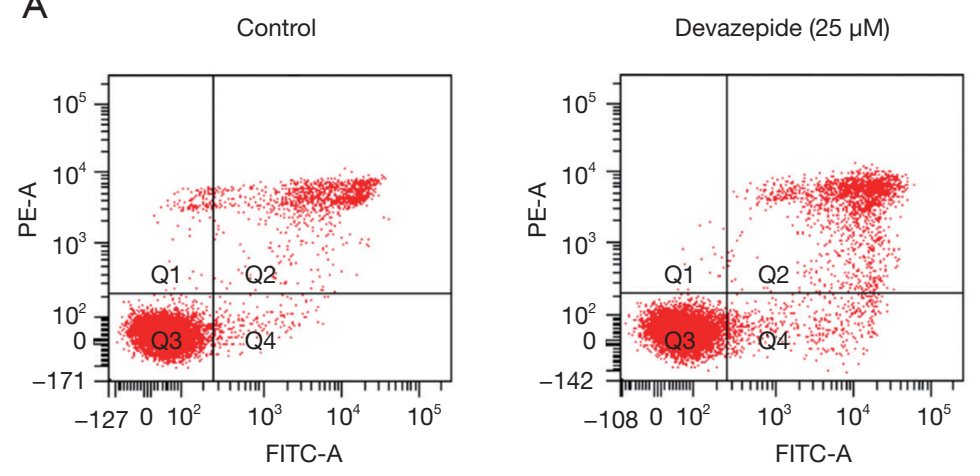

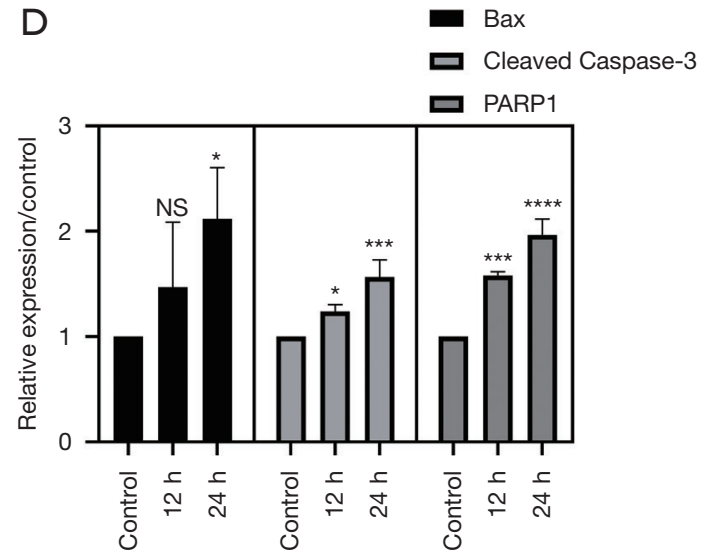

B

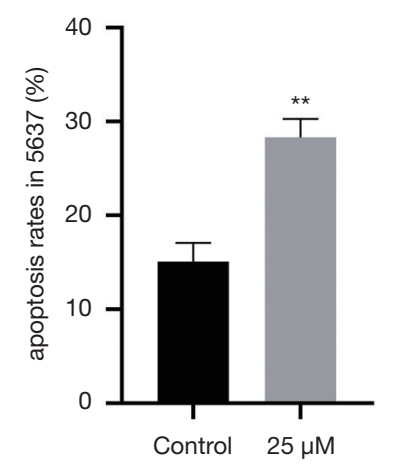

C

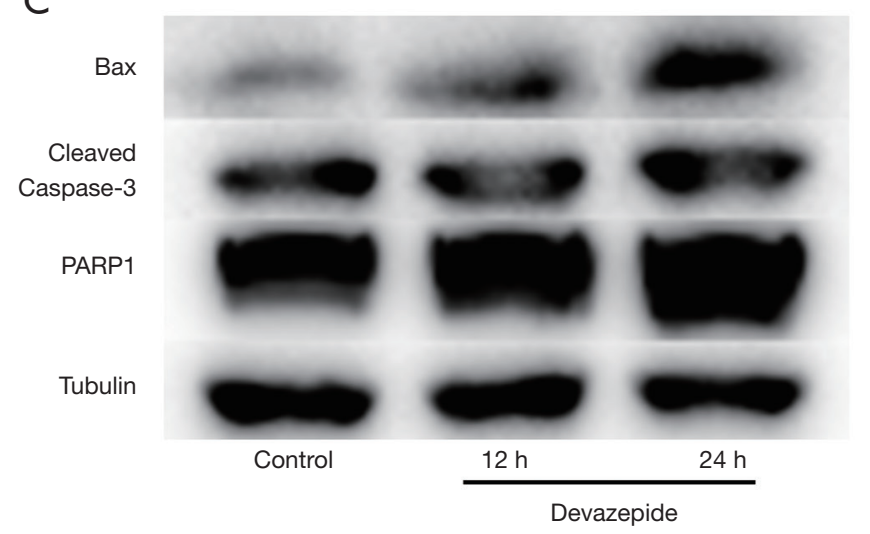

Figure 3 Devazepide promoted apoptosis in human BC 5637 cells. We collected 5637 cells cultured in medium containing devazepide (0 or $25 \mu \mathrm{M}$ ) for $48 \mathrm{~h}$ and analyzed the apoptotic cell proportion by flow cytometry (A). The values were expressed for the bar graphs as the mean $\pm \mathrm{SD}$ of independent experiments repeated 3 times $(\mathrm{B}),{ }^{* *}, \mathrm{P}<0.01$. After treatment, the expression of apoptosis-related proteins (Bax, PARP1, and Cleaved Caspase-3) were detected by a western blot. Tubulin was used as the internal control (C). We then quantified the band intensity using Image J software (D). * $\mathrm{P}<0.05 ;{ }^{* * *}, \mathrm{P}<0.001 ;{ }^{* * * *}, \mathrm{P}<0.0001$ vs. the untreated group. BC, bladder cancer; SD, standard deviation; Bax, Bcl-2-associated X protein; PARP1, poly ADP-ribose polymerase 1; NS, not significant.

of chemotherapy drugs and the drug resistance of BC cells are a major obstacle for treatment (10).

Devazepide, a benzodiazepine drug, can effectively block the CCK-mediated activation of CCK-A receptors, and is usually used to treat gastrointestinal disorders (11). In other studies, devazepide has shown potential antitumor activity, suggesting that devazepide can inhibit the proliferation of various cancer cells, such as HT-29 cells (5). It has also been reported that devazepide can restrain the metastasis of pancreatic cancer (6), and induce the apoptosis of Ewing tumor cells (7). It has been reported that, the CCKR signaling pathway is triggered by CCKAR and CCKBR, which are supposed to influence the expression of downstream genes (BCL2, CCND1, MYC, PTEN, RHOA,
SP1) and affect cell survival, angiogenesis, and invasion in human BC (8).

Tumor growth depends on the balance between cell proliferation and apoptosis. Our research is the first to confirm the anti-tumor effects of devazepide on human 5637 BC cells. Between the devazepide-treated group and the untreated control group, the in-vitro cell-function test results showed that devazepide significantly inhibited the proliferation and promoted the apoptosis of 5637 cells in a dose- and time-dependent manner. Several scientific studies have shown that Ki67, which is a cell marker of proliferation, can regulate ribosomal ribonucleic acid transcription and is closely related to the cell proliferation of BC (12) and renal cancer (13). In our research, we 
A

$$
\text { Control }
$$

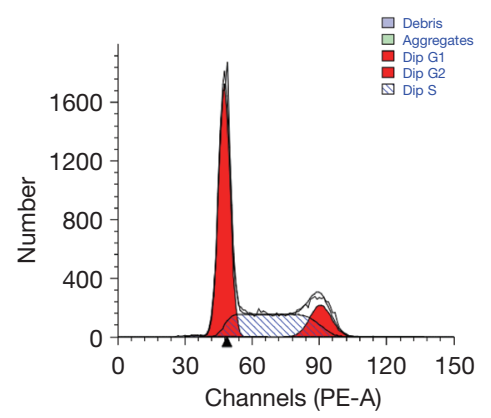

Devazepide (25 $\mu \mathrm{M})$

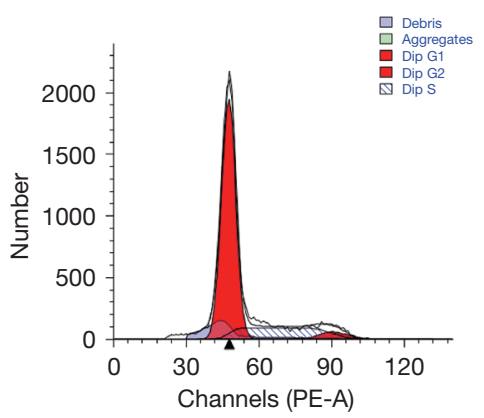

B

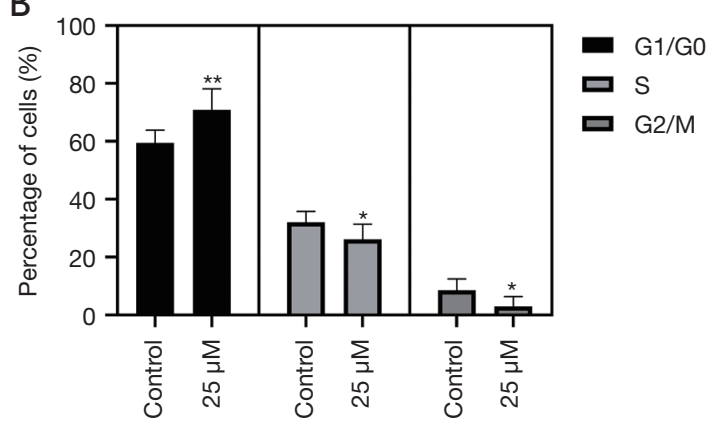

C

C

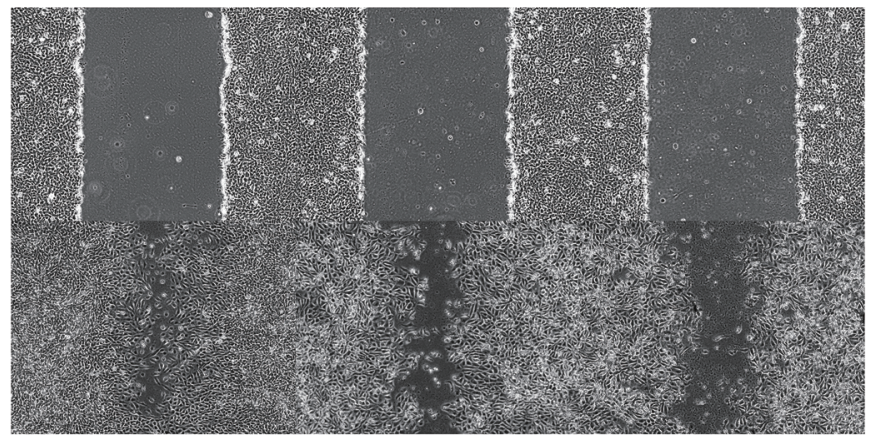

$48 \mathrm{~h}$

Devazepide

$0 \mu \mathrm{M}$

$25 \mu \mathrm{M}$

$50 \mu \mathrm{M}$

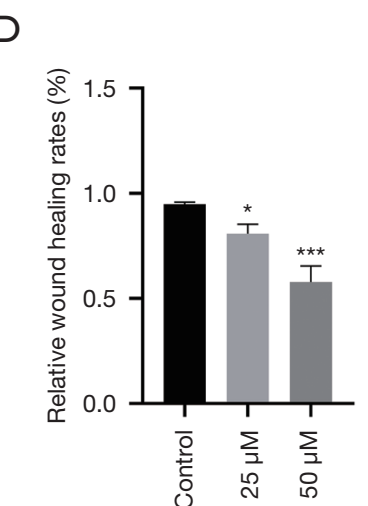

Figure 4 Devazepide induced G1/G0 phase cell cycle arrest and restrained migration in BC 5637 cells. Flow cytometry was performed in devazepide-treated/untreated 5637 cells to determine the cell phase populations with PI labeling. As the percentage of cells in each cell cycle phase showed (A), devazepide-mediated inhibition of proliferation in 5637 cells occurred as a result of G1-S cell cycle arrest (B). After incubation with FBS free DMEM containing devazepide $(0,25$ or $50 \mu \mathrm{M})$ for $48 \mathrm{~h}(\mathrm{C})$, we recorded images of the wounded areas and assessed the amount of the invading cells by analyzing the wound closure by Image $\mathrm{J}(\mathrm{D}) .{ }^{*}, \mathrm{P}<0.05 ;{ }^{* *}, \mathrm{P}<0.01 ;{ }^{* * *}, \mathrm{P}<0.001$. $\mathrm{BC}$, bladder cancer; FBS, fetal bovine serum; DMEM, Dulbecco's modified Eagle's medium.

observed that the fluorescence intensity for Ki67 in 5637 cells treated with devazepide decreased, which seems to be an important sign of cell proliferation inhibition in the presence of devazepide. During the whole cell growth, the speed of cell proliferation is controlled by the cell cycle, which leads to deoxyribonucleic acid and cells being divided and replicated to produce progeny cells (14). The cell cycle in cells with nuclei consists of two periods; that is, the interphase and the mitotic phase (including mitosis and cytokinesis). Cell cycle is mainly regulated by two checkpoints (i.e., G1/S and G2/M). Transition from the G1 to the $S$ phase is key to cell cycle progression, during which most proliferation-associated gene events occur (15). When treated with devazepide, the 5637 cells in the G1/G0 phase increased significantly, and there was also a significant decrease cells in the $S$ phase and the G2/M phase. Thus, devazepide induces G1-S cell cycle arrest in human BC
5637 cells.

The G1-phase to S-phase transition is regulated by cyclins and cyclin-dependent protein kinase (CDK). CyclinD1 forms active cyclin D/CDK4/CDK6 complexes in which CDK4 or CDK6 act as regulatory subunits for progression beyond G1-S transition (16). The induction of CyclinD1 is a rate-limiting event for the activation of CDK4 and CDK6, and the subsequent transcription of cyclin E gene promoting the transition of cells from the G1 to $S$ phase. We found that when treated with devazepide, the expression of CyclinD1 was reduced in 5637 cells. Thus, devazepide inhibits the proliferation of 5637 cells, and the mechanism of action is related to cell cycle arrest in the G1$\mathrm{S}$ phase, which is properly induced by the downregulation of the cell cycle regulatory protein CyclinD1.

Apoptosis, a universal efficient cellular suicide pathway, is a trigger of programmed cell death (17). We performed 
flow cytometry assays and found that devazepide induces apoptosis in 5637 cells. Bax, an important homolog of Bcl-2, promotes the permeabilization of the mitochondrial outer membrane, leading to intrinsic apoptosis (18). Caspase-3, an effector caspase that leads to the demise of a cell, recognizes different target proteins and cleaves short amino-acid sequences (19). The results of the western blot assay showed that devazepide increased Bax, Cleaved Caspase-3, and PARP1 protein expression, and induced apoptosis in 5637 cells, related to the mitochondrial pathway.

The results also indicated that devazepide significantly inhibited the migration of 5637 cells, which are the leading causes of recurrence and metastasis in BC. The pharmacokinetic and pharmacodynamic properties of devazepide have been studied in detail, and research has shown that devazepide by itself is not nephrotoxic and is well tolerated in several species, including humans $(20,21)$.

\section{Conclusions}

The study indicated that devazepide inhibited the proliferation of human BC 5637 cells through G1-S cell cycle arrest and induced cell apoptosis. These results suggest that devazepide may provide a novel prospective treatment option for human BC.

\section{Acknowledgments}

Funding: This study was partially funded by grants from the Research Program of Wuxi Health and Family Planning Commission (Q201612).

\section{Footnote}

Reporting Checklist: The authors have completed the MDAR reporting checklist. Available at http://dx.doi.org/10.21037/ tau-21-409

Data Sharing Statement: Available at http://dx.doi. org/10.21037/tau-21-409

Conflicts of Interest: All authors have completed the ICMJE uniform disclosure form (available at http://dx.doi. org/10.21037/tau-21-409). The authors have no conflicts of interest to declare.

Ethical Statement: The authors are accountable for all aspects of the work in ensuring that questions related to the accuracy or integrity of any part of the work are appropriately investigated and resolved.

Open Access Statement: This is an Open Access article distributed in accordance with the Creative Commons Attribution-NonCommercial-NoDerivs 4.0 International License (CC BY-NC-ND 4.0), which permits the noncommercial replication and distribution of the article with the strict proviso that no changes or edits are made and the original work is properly cited (including links to both the formal publication through the relevant DOI and the license). See: https://creativecommons.org/licenses/by-nc-nd/4.0/.

\section{References}

1. Siegel RL, Miller KD, Fuchs HE, et al. Cancer statistics, 2021. CA Cancer J Clin 2021;71:7-33.

2. Boffetta P. Tobacco smoking and risk of bladder cancer. Scand J Urol Nephrol Suppl 2008;(218):45-54.

3. Kamat AM, Hahn NM, Efstathiou JA, et al. Bladder cancer. Lancet 2016;388:2796-810. Erratum in: Lancet 2016;388:2742.

4. Konstantakou EG, Voutsinas GE, Velentzas AD, et al. 3-BrPA eliminates human bladder cancer cells with highly oncogenic signatures via engagement of specific death programs and perturbation of multiple signaling and metabolic determinants. Mol Cancer 2015;14:135.

5. González-Puga C, García-Navarro A, Escames G, et al. Selective CCK-A but not CCK-B receptor antagonists inhibit HT-29 cell proliferation: synergism with pharmacological levels of melatonin. J Pineal Res 2005;39:243-50.

6. Matters GL, Cooper TK, McGovern CO, et al. Cholecystokinin mediates progression and metastasis of pancreatic cancer associated with dietary fat. Dig Dis Sci 2014;59:1180-91.

7. Carrillo J, Agra N, Fernández N, et al. Devazepide, a nonpeptide antagonist of CCK receptors, induces apoptosis and inhibits Ewing tumor growth. Anticancer Drugs 2009;20:527-33.

8. Amuran GG, Eyuboglu IP, Tinay I, et al. New insights in bladder cancer diagnosis: urinary miRNAs and proteins. Med Sci (Basel) 2018;6:113.

9. Huang XX, Wang RX, Lin Q, et al. Inhibitory effects of 2-methoxyestradiol on cell growth and invasion in human bladder cancer T-24 cells. Pharmazie 2017;72:87-90.

10. Zhou L, Wei E, Zhou B, et al. Anti-proliferative benefit of curcumol on human bladder cancer cells via inactivating 
EZH2 effector. Biomed Pharmacother 2018;104:798-805.

11. Scarpignato C, Varga G, Corradi C. Effect of CCK and its antagonists on gastric emptying. J Physiol Paris 1993;87:291-300.

12. Pichu S, Krishnamoorthy S, Shishkov A, et al. Knockdown of Ki-67 by dicer-substrate small interfering RNA sensitizes bladder cancer cells to curcumin-induced tumor inhibition. PLoS One 2012;7:e48567.

13. Zheng JN, Pei DS, Mao LJ, et al. Inhibition of renal cancer cell growth in vitro and in vivo with oncolytic adenovirus armed short hairpin RNA targeting Ki-67 encoding mRNA. Cancer Gene Ther 2009;16:20-32.

14. Wang JD, Levin PA. Metabolism, cell growth and the bacterial cell cycle. Nat Rev Microbiol 2009;7:822-7.

15. Yamaguchi T, Cubizolles F, Zhang Y, et al. Histone deacetylases 1 and 2 act in concert to promote the G1-to-S progression. Genes Dev 2010;24:455-69.

16. Qie S, Diehl JA. Cyclin D1, cancer progression, and opportunities in cancer treatment. J Mol Med (Berl) 2016;94:1313-26.

Cite this article as: Zhang $\mathrm{H}$, Bao X, Zhang J, Hu Q, Wei B. Devazepide suppresses cell proliferation and migration, and induces apoptosis in bladder carcinoma. Transl Androl Urol 2021;10(5):2113-2121. doi: 10.21037/tau-21-409
17. Böhm I, Schild H. Apoptosis: the complex scenario for a silent cell death. Mol Imaging Biol 2003;5:2-14.

18. Birkinshaw RW, Czabotar PE. The BCL-2 family of proteins and mitochondrial outer membrane permeabilisation. Semin Cell Dev Biol 2017;72:152-62.

19. Pandey P, Bajpai P, Siddiqui MH, et al. Elucidation of the chemopreventive role of stigmasterol against Jab1 in gall bladder carcinoma. Endocr Metab Immune Disord Drug Targets 2019;19:826-37.

20. Smith JP, Kramer S, Bagheri S. Effects of a high-fat diet and L364,718 on growth of human pancreas cancer. Dig Dis Sci 1990;35:726-32.

21. Boyle SJ, Tang KW, Woodruff GN, et al. Characterization of CCK receptors in a novel smooth muscle preparation from the guinea-pig stomach by use of the selective antagonists CI-988, L-365,260 and devazepide. Br J Pharmacol 1993;109:913-7.

(English Language Editor: L. Huleatt) 